\title{
The Model of Etnomathematics for High Schools Based on the Dancers Position Movement of Beskalan Putri Malang Dance
}

\author{
Elly Susanti ${ }^{1, *}$, Moh. Miftakhul Ulum ${ }^{1}$, Turmudi $^{1}$, Maskub $^{2}$ \\ ${ }^{1}$ Mathematics Education Masters Program, Islamic State University of Maulana Malik Ibrahim Malang, 65144, \\ Indonesia \\ ${ }^{2}$ Universitas Islam Darul Ulum, Lamongan, Indonesia \\ *Corresponding author.Email: ellysusanti@mat.uin-malang.ac.id
}

\begin{abstract}
The purpose of this paper is to discover the ethnomathematical potential through the exploration of mathematical concepts in the dancers position movement. It's executed as an effort to answer the challenges of PISA 2018 and present a contextual mathematics learning resource in corresponding with the Indonesian government policy on learning during the Covid-19 pandemic. One of the traditional dances that can be used as an ethnomatematic potential is the Beskalan Putri Malang dance. This dance can be explored based on the movement of dancers position. Then, this model can present a real experience of abstract mathematical concepts. Furthermore, this paper presents several developments based on the exploration of mathematical concepts in Chacarera dance. The mathematical concepts contained in the dance are only limited to the two dimensional spaces, while in this paper are advanced geometry.

The qualitative research with a case study approach is used in this paper. The research data are obtained through interviews, documentations, and field notes. Data analysis is carried out through the following steps: 1) planning an exploration of mathematical concepts in the Beskalan Putri Malang dance, 2) sketching the movement of choreography performed by dancers, 3) generating ideas when connecting from one dance movement to another, 4) determining mathematical concepts based on the sketches that have been made, 5) verifying the suitability of mathematical concepts with the understanding of the concepts, and 6) evaluating and reviewing the results of exploration carried out. The results shows that the mathematical concepts included in the Beskalan Putri Malang dance are geometric transformations that contain the concept of translation, rotation, reflection, dilation, and composition of transformation, so that it can be a source of contextual mathematics learning for high school students. Thus, further research is needed to see how students think about building mathematical connections through the exploration of mathematical concepts in The Beskalan Putri Malang dance.
\end{abstract}

Keywords: ethnomathematics, dancers position movement, beskalan putri malang dance

\section{INTRODUCTION}

Applying mathematical concepts based on real problems is part of the standard process that students must have [1][2][3]. However, many of them find it difficult to apply. It's proven based on the achievement of Programme for International Student Assessment (PISA) survey result in 2018 which showed that high school students of Indonesia in mathematics scored 379 out from the average of 489 which is about $28 \%$ of students who are able to get the minimum competency limit [4]. Based on this result, the treatment that can be used is to bring learning integrated with the real world context [5]. Thus, the effort to bring the connection between mathematical concepts and culture around students is necessary to be implemented in the classroom [6][7]. It's strengthened by the results of Febriani's research which states that this effort can improve the understanding of mathematical concepts for high school students [8]. Then, it's known as ethnomathematics [9].

On the other hand, education sectors around the world including Indonesia are facing school closures as an effort to overcome the Covid-19 pandemic. Learning switches to a distance learning system by using the internet. In addition, the Indonesian government also provided adjustments to the learning policy during the Covid-19 pandemic with an emergency curriculum by simplification. In this case teachers can focus on essential and contextual learning with real life [10]. Therefore ethnomathematics is still relevant to be used as an effort to present contextual mathematical learning with a culture around students. 
The relationship between mathematics and cultural context is inseparable [11][12][13]. The students often don't realize that there are various mathematical concepts used in daily life, even more in their customs and culture [13]. The similar case also occures in Malang customs and culture. One of the underlying factors is the lack of studies on ethnomathematics related to the local culture and wisdo. Factually, Malang has a variety of distinctive arts that can be raised as ethnomatematic potential. One of it is Beskalan Putri Malang dance.

The Beskalan Putri Malang dance is one of the typical dances in Malang that has not been widely known by indonesian people [14]. The dance has been known since the 1930s [15]. In the past this dance served as a ritual of worship at the request of safety, fertility, and health to ancestors [16]. But now the dance is switching the functions as a performers event while welcoming the guests [14].

Exploring the mathematical concepts in traditional dance can present an experience or physical sensation. Traditional dance exploration studies include movement, rhythm, geometry, and more [7]. Some previous researches that specifically examined the exploration of mathematical concepts in traditional dances are the Argentine Chacarera dance [16][17], Sigeh Paguten Lampung dance [19], Zapin Panyengat dance [20], East Hambawang dance [21], Sekapur Sirih Riau dance [22], Kejei Rejang Lebong dance [23], and Jejer Gandrung Kembang Menur dance [24]. Some of these studies focus on dancer position movements that can produce formation of dancers like in two dimensional spaces in flat shapes. Therefore, this study aims to explore the mathematical concepts in the dencers position movements of Beskalan Putri Malang dance as an effort to answer the PISA 2018 challenges and to present a contextual mathematics learning resource during the Covid-19 pandemic.

\subsection{Our Contribution}

This paper presents some improvements based on the exploration of mathematical concepts on Chacarera dance in Sardella [17]. The additional view used in this paper is presenting by different dance in Indonesia. Then, the mathematical concepts contained in the Chacarera dance are only limited to the two dimensional spaces, while in this paper are advanced geometry.

\subsection{Paper Structure}

This paper is organized as follows. Section 1 provides the introduction used and the contribution carried out in this paper. Section 2 presents a literature reviews that include ethnomatematics, mathematical concepts, Beskalan Putri Malang dance, and research methods. Then, a discussion of the exploration of mathematical concepts in Beskalan Putri Malang dance is in Section 3.
Finally, Section 4 concludes the paper and provides some directions for the future research.

\section{MATERIALS AND METHOD}

\subsection{Etnomathematics}

Etymologically, ethnomathematics comes from the word of ethno which refers to a sociocultural context which contains language, jargon, code of behavior, myths, and symbols; the word of mathema which means explaining, knowing, understanding, and carrying out activities such as coding, measuring, classifying, ordering, concluding, and making models; and the word of tics which comes from techne and has the same roots as art and engineering [25]. In terminology, D'Ambrosio [9] states that ethnomatematics is a term used to describe the relationship between culture and mathematics. The main objective of the ethnomathematics program is to offer an innovative theoretical basis structured by the philosophical, political, and epistemological dimensions of developing mathematical knowledge as well as understanding human behavior by understanding mathematical ideas and procedures [26]. Another purpose of ethnomatematics is to explore mathematical ideas contained in the context of cultural activities in a community [12].

Some mathematical studies related to culture can be carried out based on the following points of view: 1) looking at the application of mathematics in real life, 2) exploring mathematical concepts in culture, 3) teaching mathematics based on local culture, 4) looking at the integration of mathematics and culture, and 5) analyzing mathematical community activities [27].

Based on the study models above, this paper will specifically focus to explore the mathematical concepts contained in the culture of the Beskalan Putri Malang dance. This paper refers to research conducted by Sardella [17] who has explored the mathematical concept in Argentine Chacarerea dance. The results of Sardella's research explain that the dancers position movements of the Chacarera dance choreography can present some geometric shapes presented in Table 1 [17].

Table 1 Mathematical Concepts in Chacarera Dance

\begin{tabular}{|c|l|l|}
\hline Steps & Movement Name & Mathematical Concept \\
\hline \hline 1 & Avance y retroceso & Rhombuses \\
\hline \hline 2 & Giro & Circumferences \\
\hline \hline 3 & Vuelta entera & Circumferences \\
\hline \hline 4 & Zapateo y zarandeo & Rhombus \\
\hline \hline 5 & Vuelta entera & Circumferences \\
\hline \hline 6 & Zapateo y zarandeo & Rhombus \\
\hline \hline 7 & Media vuelta & semicircumference \\
\hline \hline 8 & Giro y coronación & Circumferences \\
\hline
\end{tabular}

The mathematical concept of the Chacarera dance can be seen through the illustration in Figure 2.1 below. Note that the numbers in the figure indicate the sequence of steps according to Table 2.1 . 


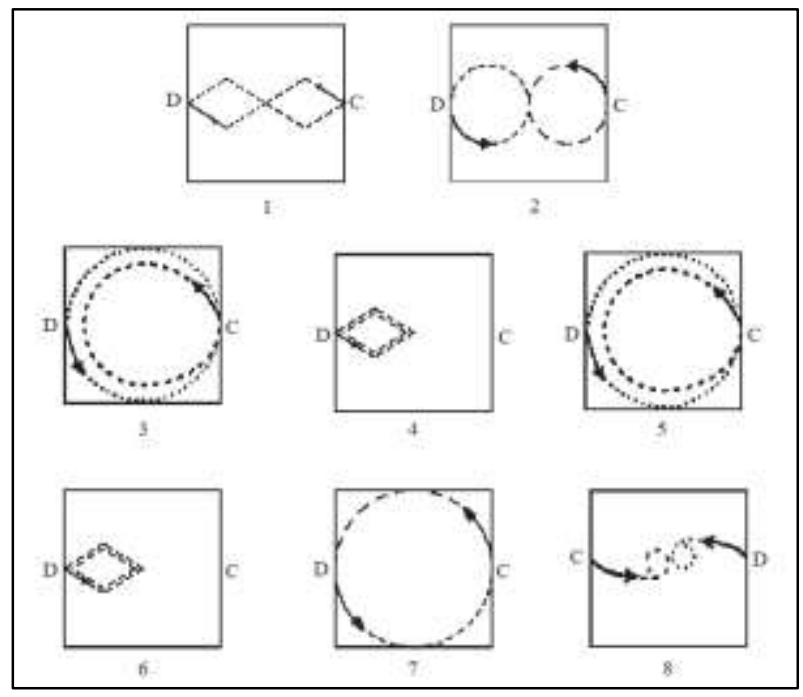

Figure 2.1 Mathematical Concept of Chacarera Dance Floor Patterns

\subsection{Mathematical Concepts}

Etymologically, the word of concept (conceptrum) means a direct object of thought or general idea [28]. Godino [29] states that a concept can be interpreted as an attempt to obtain the meaning from an object. According to Vergnaud, a concept requires a set of characteristics that define the concept, a particular symbolic representation, and the meaning of the concept. The properties that can accompany a mathematical concept, such as commutative, associative, and identity operators in the addition of real numbers [30]. Furthermore, Carraher [30] states that a concept does not apply to one situation only, but can be used in several situations which have meaning in the concept.

\subsection{Beskalan Putri Malang Dance}

The origin of the word Beskalan is the word of bit and kal (as in the local Javanese language). Bit means bibit or seed and kal means cikal or beginning. Then the two words are combined into the word of bibit kawit which means origin. This term refers to the word of cikal that related to coconut fruit and is used as Beskalan gending (music) or kelopo ndek (short coconut) music [15].

This dance is known by the local community since the 1930s [15]. Formerly, this dance is functioned as an offering ritual at the request of safety, fertility, and health to the ancestors [16]. But now this dance has changed its function as a guest welcoming ceremony [14]. The various movements of the Putri Beskalan dance are sequentially as follows: 1) gejuk entran, 2) sirig linglingan, 3) singget kebyok, 4) gejug singget, 5) gejug kanan kiri, 6) gejug lombo, 7) junjungan, 8) gejug mundur, singget kebyok, 9) kepat sempur, 10) ukel suweng, 11) ngrawit 3x seblak wiwir sampur, 12) ngrawit atas bawah, 13) ceklekan lombo, 14) rangkep, 15) sekar suwun, 16) singget puketan,
17) gejug mundur, labas lombo, njluwat samping, 18) lebah rangkep, 19) kontrengan/rangkep, 20) gejug, seblak sempur, 21) gejug mundur, gedrugan, singget, 22) lampah telu, 23) pentangan samping kiri, 24) kebyok, labas, ayam alas, sirig linglingan, 25) bumi langit, and 26) sembahan.

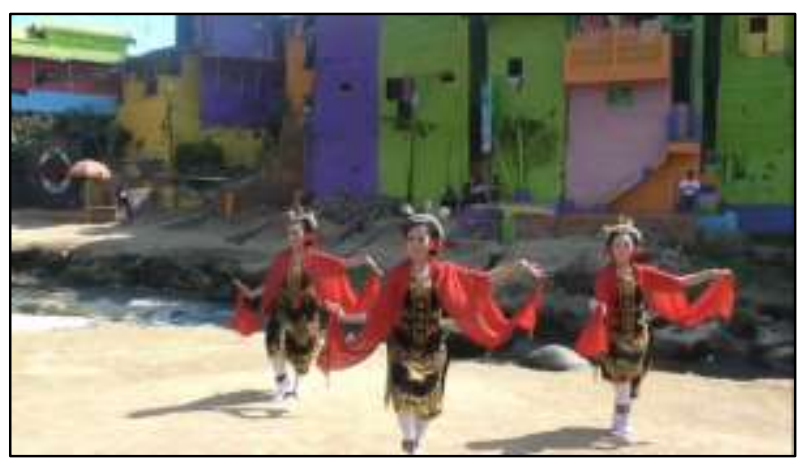

Figure 2.2 Besakalan Putri Malang Dance

\subsection{Research Methods}

This paper is a qualitative research with a case study approach. It aims to describe and analyze the activities of the Beskalan Putri Malang dance in depth. The research data are obtained through interviews (with cultural academics, active artists, and historians), documentations, and field notes. Data analysis was carried out through the following steps: 1) planning an exploration of mathematical concepts in the Beskalan Putri Malang dance, 2) sketching the movement of choreography or floor patterns performed by dancers, 3) generating ideas when connecting from one dance movement to another, 4) determining mathematical concepts based on the sketches that have been made, 5) verifying the suitability of mathematical concepts with the understanding of the concepts, and 6) evaluating and reviewing the results of exploration carried out.

\section{DISCUSSION}

The results show that cultural heritage such as dance is still interested and maintained by the residents of Malang, especially the Beskalan Putri Malang dance. The origin of this dance is adopted from the andong or traveling singers (ie. female dancer who brings her children around to sing). Then this dance is reorganized by Chattam Ahmad Redjo in the 1970s. This rearrangement is a short version of the Beskalan Putri Malang dance [31]. This dance has been existing until now with some functions for performances and ceremonial welcoming guests such as the opening of a new campus, wedding event, and others. Furthermore, based on the artists point of view, if this dance is used as a learning resource in mathematics learning, it will be able to present a more interesting learning because it is more contextual or has a clear application. On the other hand, these efforts can also grow up a sense of love for the culture around of them [32]. 
The mathematical concepts contained in the Beskalan Putri Malang dance are the transformation of geometric which includes translation, rotation, reflection, dilation, and transformation composition.

\section{Translation}

The concept of translations contained in the Beskalan Putri Malang dance can be seen in the following movements: 1) gejuk entran, 2) sirig linglingan,, 4) gejug singget, 5) gejug kanan kiri, 7) junjungan, 8) gejug mundur, singget kebyok, 14) rangkep, 15) sekar suwun, 16) singget puketan, 17) gejug mundur, labas lombo, njluwat samping, 18) lebah rangkep, 20) gejug, seblak sempur, 21) gejug mundur, gedrugan, singget, 22) lampah telu, 24) kebyok, labas, ayam alas, sirig linglingan, 25) bumi langit, and 26) sembahan. The movements performed by dancers are sometimes not simultaneously. For example, in the sirig linglingan movement, translation is only performed by a dancer while the other two dancers don't move. The formula used is as follows.

$$
A(x, y) \stackrel{T\left(\begin{array}{l}
a \\
b
\end{array}\right)}{\longrightarrow} A^{\prime}\left(x^{\prime}, y^{\prime}\right)
$$

\section{Rotation}

The concept of rotations contained in the Beskalan Putri Malang dance can be seen in the following movements: 12) ngrawit atas bawah, 17) gejug mundur, labas lombo, njluwat samping, 18) lebah rangkep, and 22) lampah telu. The rotation performed by the dancer is executed as counterclockwise. The rotation angles used are $90^{\circ}, 180^{\circ}$, and $270^{\circ}$. The center point, when the dancers rotate, can be the same point or each dancer has the unique center point. For example, in the lempah telu movement, each dancer has center point with a rotation angle of $270^{\circ}$ counterclockwise. The formula used is as follows.

$$
A(x, y) \stackrel{P_{[(a, b), \alpha]}}{\longrightarrow} A^{\prime}\left(x^{\prime}, y^{\prime}\right)
$$

\section{Reflection}

The concept of reflections can be found in every movement except gejug entran. Reflection is done by mirroring two dancers based on the dancers position in the middle. So that the mirror used is about the $x$ and $y$ axes. The formula used is as follows.

$$
A(x, y) \stackrel{R_{y} \text { axe }}{\longrightarrow} A^{\prime}\left(x^{\prime}, y^{\prime}\right)
$$

Dilation

The concept of dilations contained in the Beskalan Putri Malang dance can be seen in the following movements: 17) gejug mundur, labas lombo, njluwat samping, and 24) kebyok, labas, ayam alas, sirig linglingan. The dilations are executed by enlarging and shrinking the dancers formation based on the same shape. The formula used is as follows:

$A(x, y) \stackrel{D_{[o(a, b), k]}}{\longrightarrow} A^{\prime}\left(x^{\prime}, y^{\prime}\right)$

\section{Composition of transformation}

The concept of transformation compositions contained in Beskalan Putri Malang dance can be seen in the following movements: 4) gejug singget, 5) gejug kanan kiri, 7) junjungan, 8) gejug mundur, singget kebyok, 14) rangkep, 15) sekar suwun, 16) singget puketan, 17) gejug mundur, labas lombo, njluwat samping, 18) lebah rangkep, 20) gejug, seblak sempur, 21) gejug mundur, gedrugan, singget, 24) kebyok, labas, ayam alas, sirig linglingan, 25) bumi langit, and 26) sembahan. The use of compositions found in dance movement can be constructed through some kind of transformation or mixed. For example, the gejug singget movement contains the translation for three times. So that the formula can be written as follows.

$$
A(x, y) \stackrel{T_{3}\left(\begin{array}{l}
a_{3} \\
b_{3}
\end{array}\right) \circ T_{2}\left(\begin{array}{l}
a_{2} \\
b_{2}
\end{array}\right) \circ T_{1}\left(\begin{array}{l}
a_{1} \\
b_{1}
\end{array}\right)}{\longrightarrow} A^{\prime \prime \prime}\left(x^{\prime \prime \prime}, y^{\prime \prime \prime}\right)
$$

Furthermore, the mathematical concept in the Beskalan Putri Malang dance based on the dancers position

\begin{tabular}{|c|c|c|}
\hline No & $\begin{array}{c}\text { Dancers Position } \\
\text { Movements }\end{array}$ & $\begin{array}{c}\text { Mathematical } \\
\text { Concepts }\end{array}$ \\
\hline 1 & & $\begin{array}{l}\text { Translation } \\
A(x, y) \stackrel{T\left(\begin{array}{l}a \\
b\end{array}\right)}{\longrightarrow} A^{\prime}\left(x^{\prime}, y^{\prime}\right) \\
B(x, y) \stackrel{T\left(\begin{array}{l}a \\
b\end{array}\right)}{\longrightarrow} B^{\prime}\left(x^{\prime}, y^{\prime}\right) \\
C(x, y) \stackrel{T\left(\begin{array}{l}a \\
b\end{array}\right)}{\longrightarrow} C^{\prime}\left(x^{\prime}, y^{\prime}\right)\end{array}$ \\
\hline 2 & 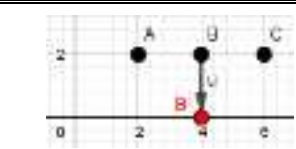 & $\begin{array}{l}\text { Translation } \\
B(x, y) \stackrel{T\left(\begin{array}{l}a \\
b\end{array}\right)}{\longrightarrow} B^{\prime}\left(x^{\prime}, y^{\prime}\right)\end{array}$ \\
\hline 2 & $1 \mathrm{f}$ ? & $\begin{array}{l}\text { Reflection } \\
A(x, y) \stackrel{R_{x=2}}{\longrightarrow} A^{\prime}\left(x^{\prime}, y^{\prime}\right) \\
C(x, y) \stackrel{R_{x=2}}{\longrightarrow} C^{\prime}\left(x^{\prime}, y^{\prime}\right) \\
A=C^{\prime} ; C=A^{\prime}\end{array}$ \\
\hline 3 & Same with & ection in no. 2 \\
\hline 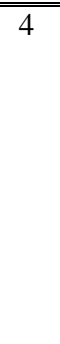 & 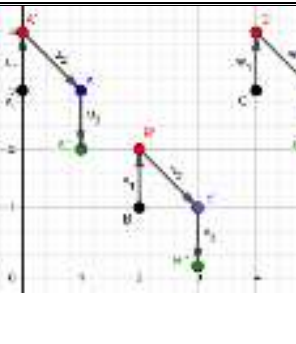 & $\begin{array}{l}\text { Translation } \\
A(x, y) \stackrel{T_{3}\left(\begin{array}{l}a_{3} \\
b_{3}\end{array}\right) \circ T_{2}\left(\begin{array}{l}a_{2} \\
b_{2}\end{array}\right) \circ T_{1}\left(\begin{array}{c}a_{1} \\
b_{1}\end{array}\right)}{\longrightarrow} \\
A^{\prime \prime \prime}\left(x^{\prime \prime \prime}, y^{\prime \prime \prime}\right) \\
B(x, y) \stackrel{T_{3}\left(\begin{array}{c}a_{3} \\
b_{3}\end{array}\right) \circ T_{2}\left(\begin{array}{c}a_{2} \\
b_{2}\end{array}\right) \circ T_{1}\left(\begin{array}{c}a_{1} \\
b_{1}\end{array}\right)}{\longrightarrow} \\
B^{\prime \prime \prime}\left(x^{\prime \prime \prime}, y^{\prime \prime \prime \prime}\right) \\
C(x, y) \stackrel{T_{3}\left(\begin{array}{l}a_{3} \\
b_{3}\end{array}\right) \circ T_{2}\left(\begin{array}{l}a_{2} \\
b_{2}\end{array}\right) \circ T_{1}\left(\begin{array}{c}a_{1} \\
b_{1}\end{array}\right)}{\longrightarrow} \\
C^{\prime \prime \prime}\left(x^{\prime \prime \prime}, y^{\prime \prime \prime}\right)\end{array}$ \\
\hline 4 & Same with $t$ & ection in no. 2 \\
\hline (5 & $9 \quad 2 \quad+4 \varphi^{2}$ & 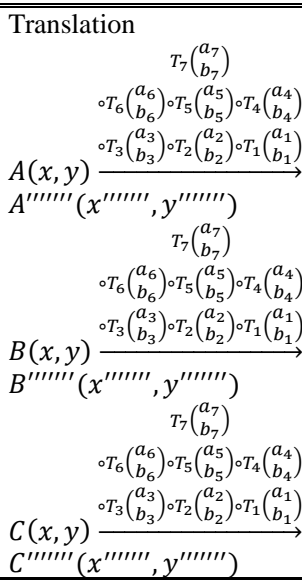 \\
\hline 5 & \multicolumn{2}{|c|}{ Same with the reflection in no. 2} \\
\hline 6 & Same with $t$ & ection in no. 2 \\
\hline
\end{tabular}
movements are presented in Table 3.1.

Table 3.1 Mathematical Concepts in the Beskalan Putri Dance 


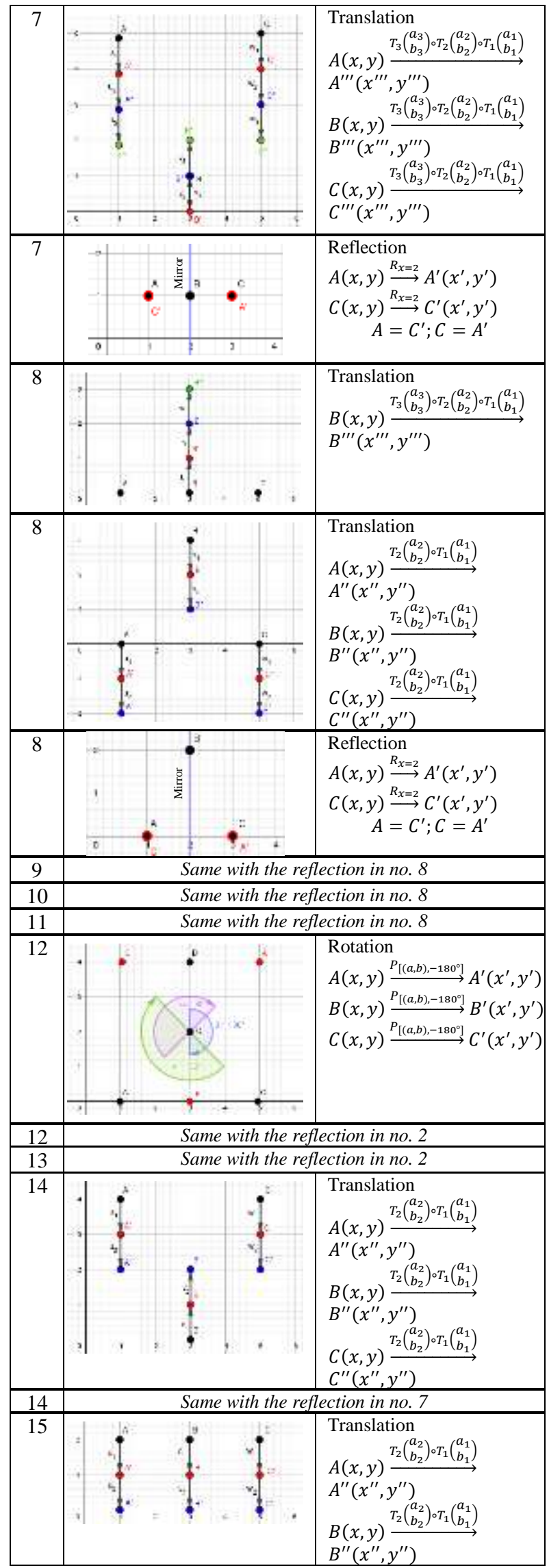

\begin{tabular}{|c|c|c|}
\hline & & $\begin{array}{l}C(x, y) \stackrel{T_{2}\left(\begin{array}{l}a_{2} \\
b_{2}\end{array}\right) \circ T_{1}\left(\begin{array}{l}a_{1} \\
b_{1}\end{array}\right)}{\longrightarrow} \\
C^{\prime \prime}\left(x^{\prime \prime}, y^{\prime \prime}\right)\end{array}$ \\
\hline & \multicolumn{2}{|c|}{ Same with the reflection in no. 7} \\
\hline 16 & 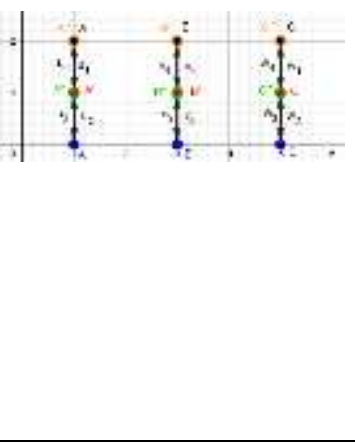 & 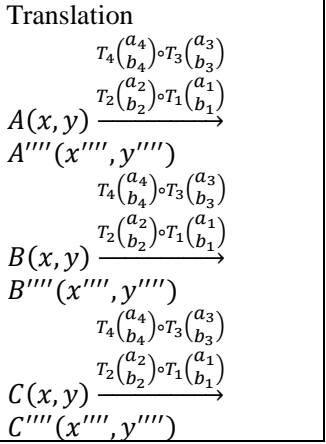 \\
\hline 16 & \multicolumn{2}{|c|}{ Same with the reflection in no. 7} \\
\hline 17 & is & 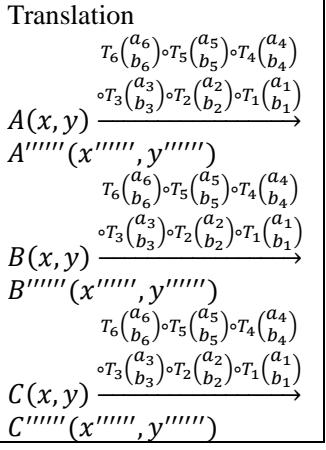 \\
\hline 17 & $\therefore+0^{\circ}$ & $\begin{array}{l}\text { Rotation } \\
A(x, y) \stackrel{P_{\left[(a, b),-180^{\circ}\right]}^{\longrightarrow}}{\longrightarrow} A^{\prime}\left(x^{\prime}, y^{\prime}\right) \\
C(x, y) \stackrel{P_{\left[(a, b),-180^{\circ}\right]}^{\longrightarrow}}{\longrightarrow} C^{\prime}\left(x^{\prime}, y^{\prime}\right) \\
\text { Translation, rotation } \\
B(x, y) \stackrel{T\left(\begin{array}{l}a \\
b\end{array}\right)}{\longrightarrow} B^{\prime}\left(x^{\prime}, y^{\prime}\right) \\
B^{\prime}\left(x^{\prime}, y^{\prime}\right) \stackrel{P_{\left[(a, b),-135^{\circ}\right]}^{\longrightarrow}}{\longrightarrow} \\
B^{\prime \prime}\left(x^{\prime \prime}, y^{\prime \prime}\right) \\
\end{array}$ \\
\hline 17 & $\mid$ & $\begin{array}{l}\text { Dilation } \\
A(x, y) \stackrel{D_{1[o(a, b), 0.5]}}{\longrightarrow} A^{\prime}\left(x^{\prime}, y^{\prime}\right) \\
A^{\prime}\left(x^{\prime}, y^{\prime}\right) \stackrel{D_{2[o(a, b), 2]}}{\longrightarrow} A(x, y) \\
B(x, y) \stackrel{D_{1[(a, b), 0.5]}}{\longrightarrow} B^{\prime}\left(x^{\prime}, y^{\prime}\right) \\
B^{\prime}\left(x^{\prime}, y^{\prime}\right) \stackrel{D_{2[o(a, b), 2]}}{\longrightarrow} B(x, y) \\
C(x, y) \stackrel{D_{1[(a, b), 0.5]}^{\longrightarrow}}{\longrightarrow} C^{\prime}\left(x^{\prime}, y^{\prime}\right) \\
C^{\prime}\left(x^{\prime}, y^{\prime}\right) \stackrel{D_{[[o(a, b), 2]}}{\longrightarrow} C(x, y) \\
\end{array}$ \\
\hline 17 & $\int_{1}^{1} \cdot \frac{5}{6}$ & $\begin{array}{l}\text { Rotation } \\
A(x, y) \stackrel{P_{\left[(a, b),-180^{\circ}\right]}^{\longrightarrow}}{\longrightarrow} A^{\prime}\left(x^{\prime}, y^{\prime}\right) \\
C(x, y) \stackrel{P_{\left[(a, b),-180^{\circ}\right)}^{\longrightarrow}}{\longrightarrow} C^{\prime}\left(x^{\prime}, y^{\prime}\right) \\
\text { Rotation, translation } \\
B(x, y) \stackrel{P_{\left[(a, b),-135^{\circ}\right]}^{\longrightarrow}}{\longrightarrow} B^{\prime}\left(x^{\prime}, y^{\prime}\right) \\
B^{\prime}\left(x^{\prime}, y^{\prime}\right) \stackrel{T\left(\begin{array}{l}a \\
b\end{array}\right)}{\longrightarrow} B^{\prime \prime}\left(x^{\prime \prime}, y^{\prime \prime}\right)\end{array}$ \\
\hline 17 & 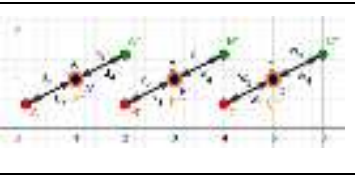 & $\begin{array}{l}\text { Translation } \\
T_{4}\left(\begin{array}{l}a_{4} \\
b_{4}\end{array}\right) \circ T_{3}\left(\begin{array}{l}a_{3} \\
b_{3}\end{array}\right) \\
A(x, y) \stackrel{T_{2}\left(\begin{array}{l}a_{2} \\
b_{2}\end{array}\right) \circ T_{1}\left(\begin{array}{l}a_{1} \\
b_{1}\end{array}\right)}{\longrightarrow} \\
A^{\prime \prime \prime \prime \prime}\left(x^{\prime \prime \prime \prime \prime}, y^{\prime \prime \prime \prime}\right)\end{array}$ \\
\hline
\end{tabular}



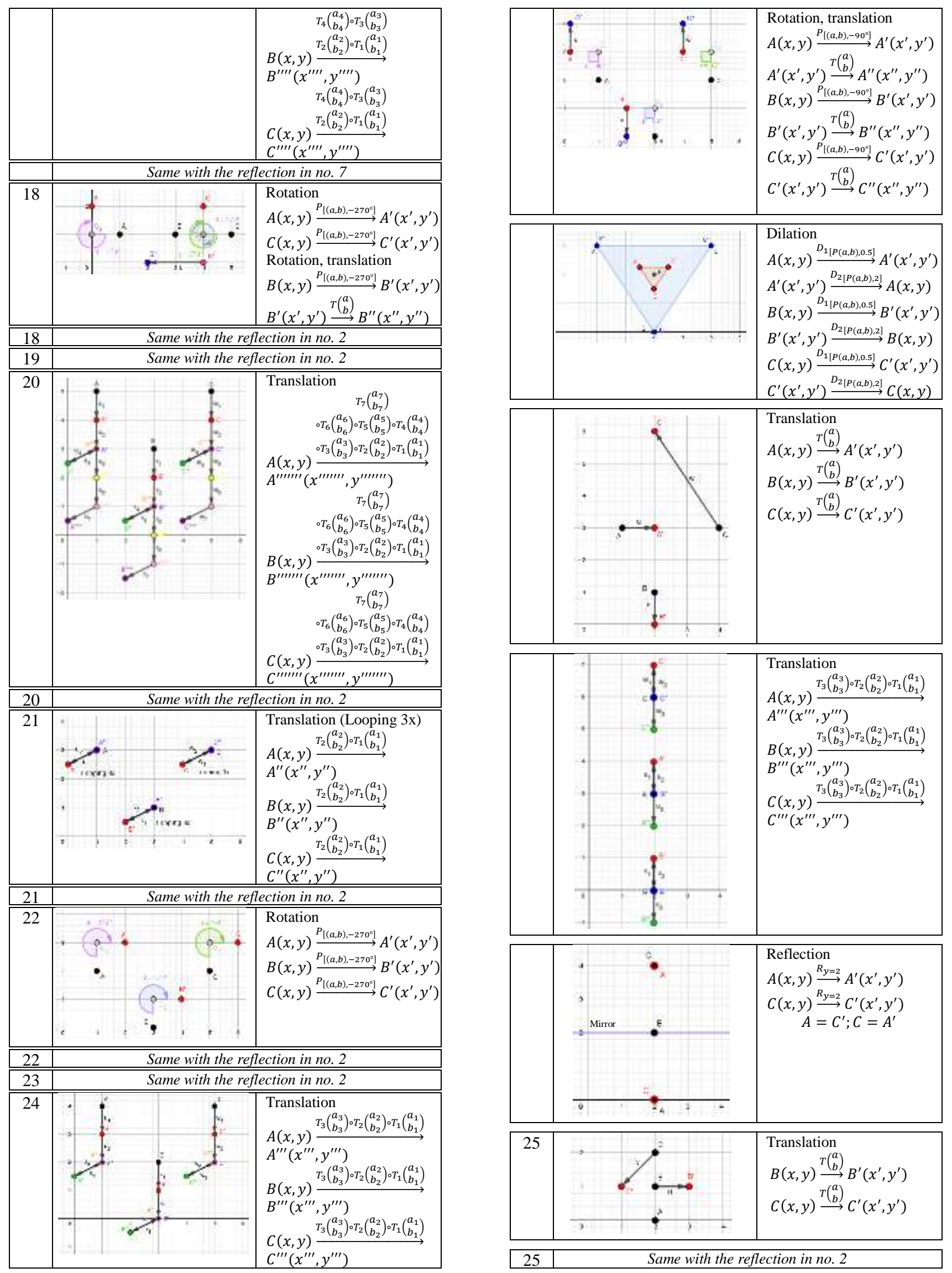


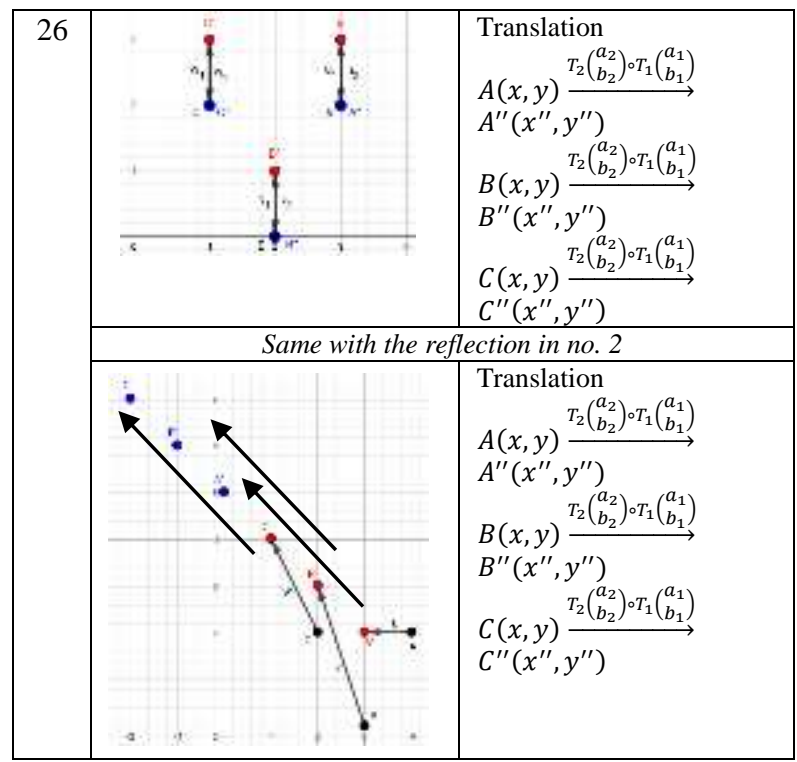

Informations:

$A, B, C: 1^{\text {st }}, 2^{\text {nd }}$, and $3^{\text {rd }}$ dancer

$\longrightarrow$ : The direction of the dancer's movement

- : The starting position of the dancer

O : $1^{\text {st }}$ step

O $: 2^{\text {nd }}$ step

O : $3^{\text {rd }}$ step

$0: 4^{\text {th }}$ step

$0: 5^{\text {th }}$ step

$0: 6^{\text {th }}$ step

○ $: 7^{\text {th }}$ step

Based on the results of research related to the concepts of translation, rotation, reflection, dilation, and the composition of transformations in the Beskalan Putri Malang dance, it can be a contextual source of learning mathematics for high school students. In addition, mathematics learning that presents the application of mathematical concepts contextually in culture can improve students external mathematical connection ability (the ability to relate mathematical concepts to real life) [33]. Thus this paper is expected to contribute for the teachers to build learning designs as the implementation of the geometric transformation concepts in real life, especially in the Beskalan Putri Malang dance.

\section{CONCLUSION}

The mathematical concepts contained in the Beskalan Putri Malang dance are a geometric transformation which includes the concepts of translation, rotation, reflection, dilation, and transformation composition. Thus the effort to present an exploration of mathematical concepts in dance can be a source of contextual mathematics learning for high school students. Further research is needed to see how the thinking process of students in building mathematical conections through the exploration of mathematical concepts in the Beskalan Putri Malang dance.

\section{ACKNOWLEDGMENT}

The authors would like to thank the Sanngar Seni Topeng Malang Asmorobangun, East Java Indonesia for allowing the research to be carried out. Errors or inconsistencies found in this paper are purely from the authors.

\section{REFERENCES}

[1] NCTM, "Principles and Standards for School Mathematics," 2000. [Online]. Available: http://www.nctm.org/uploadedFiles/Math_Stan dards/12752_exec_pssm.pdf.

[2] A. Baki, H. Çatlioğlu, S. Coştu, and O. Birgin, "Conceptions of High School Students about Mathematical Connections to The Real-Life," Procedia - Soc. Behav. Sci., vol. 1, no. 1, pp. 1402-1407, 2009, doi: 10.1016/j.sbspro.2009.01.247.

[3] M. K. Altay, B. Yalvaç, and E. Yeltekin, "8th Grade Student's Skill of Connecting Mathematics to Real Life," J. Educ. Train. Stud., vol. 5, no. 10, pp. 158-166, 2017, doi: 10.11114/jets.v5i10.2614.

[6] A. Yuristia, "Pendidikan sebagai Transformasi Kebudayaan," Ijtimaiyah J. Ilmu Sos. dan Budaya, vol. 2, no. 1, 2018, doi: 10.1017/CBO9781107415324.004.

[7] Y. Helsa and Y. Hartono, "Designing Reflection and Symmetry Learning by Using Math Traditional Dance in Primary School," IndoMS. J.M.E, vol. 2, no. 1, pp. 79-94, 2011.

[8] P. Febriani, W. Widada, and D. Herawaty, "Pengaruh Pembelajaran Matematika Realistik Berbasis Etnomatematika Terhadap Kemampuan Pemahaman Konsep Matematika Siswa SMA Kota Bengkulu," J. Pendidik. Mat. Raflesia, vol. 04, no. 02, pp. 120-135, 2019.

[9] U. D'Ambrosio, "What Is Ethnomathematics, and How Can It Help Children in Schools?," Teach. Child. Math., 2001.

[10] Dirjenpendis, Keputusan Direktur Jenderal Pendidikan Islam Nomor 2791 Tahun 2020 tentang Panduan Kurikulum Darurat pada Madrasah. Indonesia, 2020, pp. 1-17.

[11] I. Wahyuni, "Eksplorasi Etnomatematika Masyarakat Sidoarjo,” Fenom. (Jurnal Penelit. Islam Indones., 2015.

[12] Z. M. Nuh and Dardiri, "Etnomatematika dalam 
Sistem Pembilangan pada Masyarakat Melayu Riau," Kutubkhanah, vol. 19, no. 2, pp. 220238, 2017, [Online]. Available: http://ejournal.uin-

suska.ac.id/index.php/Kutubkhanah/article/view 12552.

[13] P. O. Maure, "Eksplorasi Etnomatematika pada Tarian Caci Masyarakat Mangarai Nusa Tenggara Timur," Posiding Semin. Nas. Etnomatnesia, pp. 340-347, 2018.

[14] J. A. Suryanto, H. Karnadi, Y. H. Yulianto, U. Kristen, and P. Surabaya, "Perancangan Buku Tata Rias, Kostum, dan Gerak Tari Beskalan Putri Malang," J. Desain Komun. Vis. Adiwarna, vol. 1, no. 2, pp. 1-7, 2013.

[15] R. Hidajat, "Tari Remo \& Tari Beskalan Kajian Strukturalisme Model Levi-Strauss," J. Terob, vol. 7, no. 2, pp. 1-22, 2017.

[16] C. I. R. Nita and S. Rahayu, "Pendidikan Karakter Bagi Anak Usia Sekolah Dasar Melalui Semiotik Gerak Tari Beskalan," Mimb. Sekol. Dasar, 2016, doi: 10.17509/mimbarsd.v1i1.860.

[17] O. Sardella, "La Geometría en Las Danzas Folklóricas Argentinas," Acta Latinoam. Matemática Educ., vol. 17, pp. 801-806, 2004.

[18] F. J. Perales, "Enculturation with Ethnomathematical Microporjects: From Culture to Mathematics," Enculturation with Ethnomathematical Microporjects From Cult. to Math., vol. 9, no. February 2015, pp. 1-11, 2015.

[19] R. Desmawati, "Eksplorasi Etnomatematika pada Gerak Tari Tradisional Sigeh Penguten Lampung," Universitas Islam Negeri Raden Intan Lampung, 2018.

[20] P. Lestari, N. Izzati, and L. Rosmery Tambuan, "Eksplorasi Etnomatematika pada Tari Tradisional Zapin Penyengat Sebagai Sumber Belajar Matematika Sekolah," Progr. Stud. Pendidik. Mat. FKIP, 2019.

[21] S. Dewi, A. Jabar, and R. Y. Gazali, "Etnomatematika pada perlengkapan tari bagipang masyarakat Pantai Hambawang Timur," Math Didact. J. Pendidik. Mat., 2019, doi: 10.33654/math.v5i1.467.

[22] Z. A. Yani, N. Izzati, and A. Dwinata, "Eksplorasi Etnomatematika Pada Kesenian Tari Sekapur Sirih Kepulauan Riau Sebagai Sumber Belajar Matematika Sesuai Kurikulum 2013," Eksplor. Etnomatematika Pada Kesenian Tari Sekapur Sirih Kepul. Riau Sebagai Sumber Belajar Mat. Sesuai Kurikulum 2013, 2014
[23] S. Destrianti, "Etnomatematika dalam Seni Tari Kejei Sebagai Kebudayaan Rejang Lebong," J. Equ. Teor. dan Penelit. Pendidik. Mat., 2019, doi: 10.29300/equation.v2i2.2316.

[24] S. N. Mahmuda, S. Susanto, and E. Yudianto, "ANALISIS PENGGUNAAN MEDIA VIDEO PEMBELAJARAN ETNOMATEMATIKA TARI JEJER GANDRUNG KEMBANG MENUR SEBAGAI HASIL BELAJAR SISWA," Saintifika, 2019.

[25] U. D'Ambrosio, "Ethnomatematics and Its Place in The History and Pedagogy of Mathematics," Learn. Math., vol. 5, no. 1, pp. 44-48, 1985.

[26] M. Rosa and M. E. Gavarrete, "An Ethnomathematics Overview: An Introduction," in Ethnomathematics and its Diverse Approaches for Mathematics Education, Cham: Springer International Publishing, 2017, pp. $3-$ 19.

[27] D. A. Kusuma, S. P. Dewanto, and B. Nurani, "The Role of Ethnomathematics in West Java (A Preliminary Analysis of Case Study in Cipatujah)," J. Phys. Conf. Ser., pp. 1-8, 2017.

[28] Online Etymology Dictionay, "Concept," 2020. https://www.etymonline.com/word/concept\#ety monline_v_17307.

[29] J. D. Godino, "Mathematical Concepts, Their Meanings, and Understanding," Proc. XX Conf. Int. Gr. Psychol. Math. Educ., vol. 2, pp. 1-7, 1996.

[30] T. N. Carraher, A. D. Schliemann, and D. Carraher, "Mathematical Concepts in Everyday Life," vol. 71-87, no. 41, 1988.

[31] C. Sunardi, "Making Sense and Senses of Locale through Perceptions of Music and Dance in Malang," Asian Music, vol. 41, no. 1, pp. 89-126, 2010.

[32] D. Yosopranata, Zaenuri, and Mashuri, "Mathematical connection ability on creative problem solving with ethnomathematics nuance learning model," Unnes J. Math. Educ., vol. 7, no. 2, pp. 108-113, 2018, doi: 10.15294/ujme.v7i2.25399.

[33] D. A. Kusuma, D. Suryadi, and J. A. Dahlan, "Improving External Mathematical Connections and Students' Activity Using Ethnomathematics," J. Phys. Conf. Ser., vol. 1157 , pp. 1-7, 2019, doi: 10.1088/1742$6596 / 1157 / 3 / 032120$. 